\title{
Characterisation of microorganisms responsible for EBPR in a sequencing batch reactor by using the 16S rDNA-DGGE method
}

\author{
Yuan REN ${ }^{1 *}$, Chaohai WEI and Kaijun XIAO² \\ ${ }^{1}$ College of Environmental Science and Engineering, South China University of Technology, Guangzhou, P.R.China, 510641 \\ ${ }^{2}$ College of Light Industry and Food Science, South China University of Technology, Guangzhou, P.R.China, 510641
}

\begin{abstract}
Analysis of the bacterial community in the biological phosphorus removal system is propitious to study the phosphorusremoval mechanism. The activated sludge was acclimated through a repeated anaerobic-aerobic process with glucose as carbon source for 2 months and a stable EBPR was established in an SBR. Total phosphate of the wastewater decreased by 12.43 $\mathrm{mg} \cdot \ell^{-1}$ after $4 \mathrm{~h}$ aerobic treatment while total $\mathrm{P}$ uptake in the raw sludge was $0.57 \mathrm{mg} \cdot \ell^{-1}$ under the same conditions, and the phosphate content of the sludge increased from $1.83 \%$ to $6.79 \%$. The protozoa and dominant bacteria of the two sludges were observed by optical and electron microscope. The genomic DNA of samples was extracted as the template and the 16S rDNA genes (V3 region) were amplified; denaturing gradient gel electrophoresis (DGGE) separated these amplified DNA fragments with the denaturant from $35 \%$ to $70 \%$. The DGGE profiles showed that the raw sludge, acclimated sludge and dominant bacteria in the acclimated sludge had different band patterns. The results indicated that micro-organisms were selected by the repeated anaerobic-aerobic process and some non-phosphorus accumulating organisms were eliminated. The cultured strains obtained from acclimated sludges were purified and their DNA was amplified using F27 and R1522 to $1.5 \mathrm{~kb}$; the gene sequences were located on the GenBank and they were identified as Acidovorax sp.BSB421 and Sphingomonas sp.SA-3.
\end{abstract}

Keywords: EBPR, micro-organism, DGGE, gene sequence

\section{Introduction}

Acinetobacter spp. was first identified as the bacterium responsible for enhanced biological phosphorus removal (EBPR) by Fuhs and Chen (1975). Subsequently many researchers reported its predominance in EBPR processes based on culture-dependent identification methods (Buchan, 1983; Lötter, 1985; Wentzel et al., 1988). Pseudomonas spp. (Lötter, 1984; Li et al.,2003), Moraxella spp. (Lötter, 1984), Aeromonas spp. (Lötter, 1984; Li et al.,2003), Klebsiella spp. (Gersberg et al., 1985), Pseudomonas cesicularis (Suresh et al., 1985), $\gamma$-Proteobacteria (Schuler et al.,2002; Ahn et al., 2002) and some other bacteria (Ahn et al., 2002) were isolated and identified as having phosphorusremoval ability. Over recent years, very intensive research has demonstrated that no pure cultures of Acinetobacter spp. have shown the typical characteristics of EBPR sludges with high Premoval capability (Jenkins et al., 1991; Van Loosdrecht et al., 1997) though there are some different reports (Lin et al.,2003; Okunuki et al.,2004). In fact, the poly phosphate-accumulating organisms (PAOs) in activated sludge are not a sole species and are considered as a group of micro-organisms capable of accumulating phosphate. In the traditional pure-culture methods, only those bacteria that are cultivable on the artificial medium used under the defined conditions can be isolated and identified (Mino et al., 1998). It is likely that only a minor portion of bacteria in activated sludges can grow under such conditions and can thus be detected (Wagner et al., 1993, Kämpfer et al., 1996). Since single pure-culture is not sufficient to determine

* To whom all correspondence should be addressed.

学 +0086-20-87112073; fax: +0086-20-87112874;

e-mail: ceyren@scut.edu.cn

Received 21 July 2006; accepted in revised form 7 November 2006. the predominant bacteria in the EBPR process, micro-organisms responsible for EBPR need further investigation.

To determine PAOs that are responsible for aerobic phosphorus removal in the EBPR process, we adapted the polymerase chain reaction (PCR)-denaturing gradient gel electrophoresis (DGGE) method that has been widely recognised as a powerful tool in the study of microbial ecology. DGGE is based on the electrophoresis of PCR-amplified 16S ribosomal DNA-V3 fragments in polyacrylamide gels containing a linearly increasing denaturant gradient (Muyzer et al., 1993). Different DGGE bands are separated depending on the melting behaviour of the PCR products with the same length but with different sequences, which correspond to the species. Therefore, PCR-DGGE assay allows us to analyse the microbial composition and diversity of a given system without the need to isolate individual species (Muyzer et al., 1995). It is particularly effective in analysing the microbial community structure of micro-organisms responsible for EBPR.

However, no single method is sufficient to analyse complex communities present in the biological wastewater treatment processes as quantitative and detailed information of the total community is necessary to characterise the process performance. The purpose of this study is to characterise PAOs in a sequencing batch reactor (SBR) to analyse the change in microbial community structure and to identify PAOs that perform EBPR by using PCR-DGGE.

\section{Experimental materials and methods}

\section{Materials}

Wastewater and sludge were taken from Lie-De Municipal Wastewater Treatment Plant (aerobic basin), Guangzhou, China. 
The chemical reagents for measuring the characteristics of wastewater and sludge are analysis pure. Primer 101 (5'-CGC CCG CCG CGC GCG GCG GGC GGG GCG GGG GCA CGG GGG GCC TAC GGG AGG CAG CAG-3'), 102(5'-ATT ACC GCG GCT GCT GG-3'), F27 (5'-AGA GTT TGA TCC TGG CTC AG-3'), R1522 (5'-AAG GAG GTG ATC CAG CCG CA3'), BSA, polymerase, dNTP were purchased from TaKaRa biotechnology (Dalian) Co. Ltd, GoldView staining was purchased from Beijing SBS Genetech Co., Ltd.

\section{SBR operation methods}

At room temperature, the operation of a $3.5 \ell$ SBR ( $3 \ell$ water and $0.5 \ell$ sludge) was conducted for 2 months to obtain PAOs responsible for EBPR. Activated sludge was inoculated and the reactor was operated with a $6.0 \mathrm{~h}$ cycle, consisting of a $2 \mathrm{~min}$ filling phase (with nitrogen bubbled for $2 \mathrm{~min}$ to assure anaerobic conditions during the feed), a $1.5 \mathrm{~h}$ anaerobic phase, a 4.0 $\mathrm{h}$ aerobic phase, an $0.3 \mathrm{~h}$ settling phase and a $5 \mathrm{~min}$ withdrawal phase. After one cycle, $3 \ell$ of the effluent was exchanged with an influent of the same amount and thus $7.0 \mathrm{~h}$ of the hydraulic retention time (HRT) was maintained. At the end of one cycle, $10 \mathrm{~m} \ell$ excess activated sludge was also wasted to maintain a sludge retention time (SRT) of $12.5 \mathrm{~d}$.

During the first 2 weeks, the SBR was run on urban wastewater and then it was replaced by artificial wastewater. The main components of urban wastewater and synthetic medium contained are listed in Table 1 and Table 2. The microelement nutrient solution consisted of the following compounds per litre: $2.0 \mathrm{~g} \mathrm{FeCl}_{3} \cdot 4 \mathrm{H}_{2} \mathrm{O}, 0.05 \mathrm{~g} \mathrm{H}_{3} \mathrm{BO}_{3}, 0.03 \mathrm{~g} \mathrm{CuSO}_{4} \cdot 5 \mathrm{H}_{2} \mathrm{O}$, $0.5 \mathrm{~g} \mathrm{MnCl}_{2} \cdot 4 \mathrm{H}_{2} \mathrm{O}, 0.09 \mathrm{~g} \mathrm{Na}_{2} \mathrm{MoO}_{4} \cdot 2 \mathrm{H}_{2} \mathrm{O}, 0.03 \mathrm{~g} \mathrm{ZnSO}_{4} \cdot 7 \mathrm{H}_{2} \mathrm{O}$, $2.0 \mathrm{~g} \mathrm{CoCl}_{2} \cdot 6 \mathrm{H}_{2} \mathrm{O}$, and $1.0 \mathrm{~g}$ EDTA, $36 \% \mathrm{HCl} 1 \mathrm{m \ell} .3 .5 \mathrm{~m} \ell$ microelement nutrient solution was added to the reactor in every operation.

The $\mathrm{pH}$ was maintained between 6.5 and 7.5 during the entire operation. The relevant parameters, i.e. total suspended solids (TSS), mixed liquor suspended solids (MLSS), sludge volume index (SVI), COD (chemical oxygen demand), DO (dissolved oxygen) and total phosphate (TP) were periodically measured according to Standard Methods (1992) to monitor SBR performance in this study. The protozoa and zoogloea in the sludge were observed by DMLB Q500LW (LEICA).

\section{Isolation of the bacteria}

The sludge from the reactor was put into a flask with glass beads, and after shaking $1 \mathrm{~m} \ell$ was taken out with a sterilised pipette and spread onto agar plates containing isolating culture medium. The culture medium contained $0.5 \% \mathrm{NaCl}$ and the compounds named in Table 2 ( $\mathrm{pH}$ 7.0). Cultivation took place at $30^{\circ} \mathrm{C}$ for $24 \mathrm{~h}$ and then the colonies were picked, purified and observed by TEM JEM-100CXII (JEOL Ltd.).

\section{PCR-DGGE analysis}

\section{Sampling and preparation}

$20 \mathrm{~m} \ell$ sludge samples were collected at the end of aerobic conditions, centrifuged at $12000 \mathrm{r} \cdot \mathrm{min}^{-1}$ (TG16-WS, SAITE XIANGYI, CHINA) for $5 \mathrm{~min}$ at $4^{\circ} \mathrm{C}$; the residues were recovered with 3 volume (v:v) of TE buffer (10 mM Tris-HCl, $1 \mathrm{mM}$ EDTA, pH8.0) and stirred for $5 \mathrm{~min}$. The steps were repeated three times, and then the samples were stored at $-20^{\circ} \mathrm{C}$.

\section{DNA extraction and PCR amplification}

The genomic DNA of sludge samples was extracted with an SDSbased DNA extraction method as described by Zhou et al. (1996). PCR amplification was conducted in an automated thermal cycler (PCR 9600, PE, USA) using the following steps: initial denaturing for $5 \mathrm{~min}$ at $94^{\circ} \mathrm{C}$ and 30 cycles of denaturation for $1 \mathrm{~min}$ at $94^{\circ} \mathrm{C}$, annealing for $1 \mathrm{~min}$ at $52^{\circ} \mathrm{C}$, extension for $0.5 \mathrm{~min}$ at $72^{\circ} \mathrm{C}$, followed by a final extension for $7 \mathrm{~min}$ at $72^{\circ} \mathrm{C}$. The obtained PCR mixtures were $100 \mu \ell$ which contained DNA $(2.0 \mu \ell)$ deionised $\mathrm{H}_{2} \mathrm{O}(61.5 \mu \ell), 10 \times$ PCR buffer $(10.0 \mu \ell), 25 \mathrm{mM} \mathrm{MgCl}$ $(8.0 \mu \ell), 2.5 \mathrm{mM}$ dNTP $(10.0 \mu \ell), 10 \mu \mathrm{M}$ primer $101(2.0 \mu \ell)$, $10 \mu \mathrm{M}$ primer $102(2.0 \mu \ell), 1.5 \mu \mathrm{g} \cdot \mu \ell^{-1} \mathrm{BSA}(4.0 \mu \ell)$, and $5 \mathrm{U} \cdot \mu \ell^{-1}$ DNA polymeraseTaq $(0.5 \mu \ell)$.

\section{Electrophoresis}

The electrophoretic process was carried out using the Dcode Universal Mutation Detection System (BioRad, USA). PCR products were electrophoresed in $1 \times$ TAE buffer $(40 \mathrm{mM}$ Tris$\mathrm{HCl}, 40 \mathrm{mM} \mathrm{CH}_{3} \mathrm{COOH}, 1 \mathrm{mM}$ EDTA, and $\mathrm{pH} \mathrm{8.0)} \mathrm{for} 260 \mathrm{~min}$ at $180 \mathrm{~V}$ and $60^{\circ} \mathrm{C}$ on polyacrylamide gel containing a linear gradient ranging from $35 \%$ to $70 \%$ denaturant. After electrophoresis, polyacrylamide gel was stained with GoldView staining for $30 \mathrm{~min}$, and then visualised on GDS-8000 (Ultra-Violet, USA).

\section{Sequencing}

The pure-culture predominant strains were picked and placed in $20 \mu \ell$ sterilised deionised $\mathrm{H}_{2} \mathrm{O}$, and then boiled for $5 \mathrm{~min}$ as the PCR template for 16S rDNA fragment sequencing. PCR amplification was conducted in an automated thermal cycler using the following protocol: initial denaturation for $3 \mathrm{~min}$ at $94^{\circ} \mathrm{C}$ and 30 cycles of denaturation for $1 \mathrm{~min}$ at $94^{\circ} \mathrm{C}$, annealing for $1 \mathrm{~min}$ at $54^{\circ} \mathrm{C}$, extension for $2 \mathrm{~min}$ at $72^{\circ} \mathrm{C}$, followed by a final extension for $7 \mathrm{~min}$ at $72^{\circ} \mathrm{C}$. PCR mixtures were $50 \mu \ell$ which contained deionised $\mathrm{H}_{2} \mathrm{O}(36.5 \mu \ell), 10 \times$ PCR buffer $(5.0 \mu \ell), 2.5 \mathrm{mM}$ dNTP $(5.0 \mu \ell), 10 \mu \mathrm{M}$ primer F27 $(1.0 \mu \ell), 10 \mu \mathrm{M}$ primer R1522 (1.0 $\mu \ell)$, DNA template $(1.0 \mu \ell)$, and $5 \mathrm{U} \mu \ell^{-1}$ Blend-Taq $(0.5 \mu \ell)$.

\begin{tabular}{|l|c|c|c|c|c|c|}
\hline \multicolumn{7}{|c|}{ TABLE 1 } \\
\hline Items & COD & TP & $\mathbf{N H}_{4}{ }^{+}-\mathbf{N}$ & $\mathbf{N O}_{3}^{-}-\mathbf{N}$ & $\mathbf{N O}_{2}-\mathbf{N}$ & SS \\
\hline Strength $/ \mathrm{mg}^{-} \ell^{-1}$ & $105-500$ & $1-10$ & $10-20$ & $0.5-3.0$ & $0.1-0.5$ & $200-1000$ \\
\hline
\end{tabular}

\begin{tabular}{|l|c|c|c|c|c|c|}
\hline \multicolumn{7}{|c|}{ CABLE 2 } \\
\hline Reagent & Glucose & $\mathrm{KH}_{2} \mathrm{PO}_{4}$ & $\mathrm{NH}_{4} \mathrm{CH}_{2} \mathrm{COOH}$ & $\mathrm{CaCl}_{2} \cdot 2 \mathrm{H}_{2} \mathbf{O}$ & $\mathrm{MgSO}_{4} \cdot 7 \mathrm{H}_{2} \mathrm{O}$ & $\mathrm{FeSO}_{4} \cdot 7 \mathrm{H}_{2} \mathrm{O}$ \\
\hline strength/mg $\cdot \ell^{-1}$ & 234 & 22 & 138 & 28 & 10 & 5 \\
\hline
\end{tabular}




\section{Results and discussion}

\section{Performance of phosphorus removal ability}

In South China, the average temperature in summer (Apr., May, Jun., Jul., Aug., Sep., Oct.) is $26^{\circ} \mathrm{C}$ above, and $15^{\circ} \mathrm{C}$ in winter (Nov., Dec., Jan., Feb.). The lower temperature has some negative effects on the EBPR, and the temperature above $40^{\circ} \mathrm{C}$ is even more disadvantageous. In the acclimation period, the inflow was urban wastewater; the water was replaced partly by artificial wastewater 2 weeks later in order to control the initial strength of COD, TP, $\mathrm{NH}_{4}^{+}-\mathrm{N}$ and so on. After one month, the inflow was artificial wastewater totally. The DO, MLSS, SVI and other items were steady during the subsequent experiment. The anaerobic status was maintained because of the nitrogen bubbling while the wastewater was filling. When the anaerobic period finished, the DO increased to $4.0 \mathrm{mg} \cdot \ell^{-1}$ in $30 \mathrm{~min}$ and kept in the same level during the full aerobic period. Thus the $2 \mathrm{~h}$ anaerobic $-4 \mathrm{~h}$ aerobic operation can be achieved. After more than 2 months' acclimation, a typical biochemical transformation responsible for EBPR was observed during the operation, which strongly suggested that PAOs were predominant in the reactors used in this study.

The phosphorus release and uptake rates are dependent on the initial COD, $\mathrm{DO}, \mathrm{NH}_{4}^{+}-\mathrm{N}, \mathrm{NO}_{3}^{-}-\mathrm{N}, \mathrm{NO}_{2}^{-}-\mathrm{N}$, temperature and some other factors. During multi-cycles' anaerobic-aerobic cultivation, the COD removal rate of the wastewater in the aerobic period is more than the anaerobic period, the sludge released $\mathrm{PO}_{4}^{3-}$ in the anaerobic period and excess uptake $\mathrm{PO}_{4}^{3-}$ in the aerobic period. As in Table 3, the sludge showed significant differences in the performance, and the COD, phosphorus uptake by the two sludges is shown in Fig. 1.

The raw sludge without phosphorus-removal ability decreased the TP of the solution from $8.84 \mathrm{mg} \cdot \ell^{-1}$ to $8.31 \mathrm{mg} \cdot \ell^{-1}$ in the $4 \mathrm{~h}$ aerobic period and then remained unchanged - the phosphate uptake was utilised to build the bacterial cells but could not be accumulated as poly-phosphate. The TP decreased from $12.84 \mathrm{mg} \cdot \ell^{-1}$ to $0.41 \mathrm{mg} \cdot \ell^{-1}$ by the acclimated sludge which suggested that the alternating aerobic-anaerobic operation could produce PAOs as the predominant micro-organism: In the anaerobic phase, PAOs take up the carbon sources and store them in the form of polyhydroxyalkanoates (PHAs) accompanied by degradation of poly-P and consequent release of orthophosphate; in the subsequent aerobic phase, PAOs grow aerobically and take up orthophosphate to recover the poly-P level by using the stored PHA as the carbon and energy source (Mino et al., 1998; Chen et al., 2004). Excess sludge rich in poly-P was discharged from the reactor to retain persistent phosphorus-removal ability.

\section{Characterisation of micro-organism in the sludge}

The raw and acclimated sludge was observed under the microscope. Some zoogloea and filamentous fungi exited in the raw sludge. Sphaerotilus-like, vorticellidae-like, rotifera-like and some other zoogloea were observed when the PAOs were

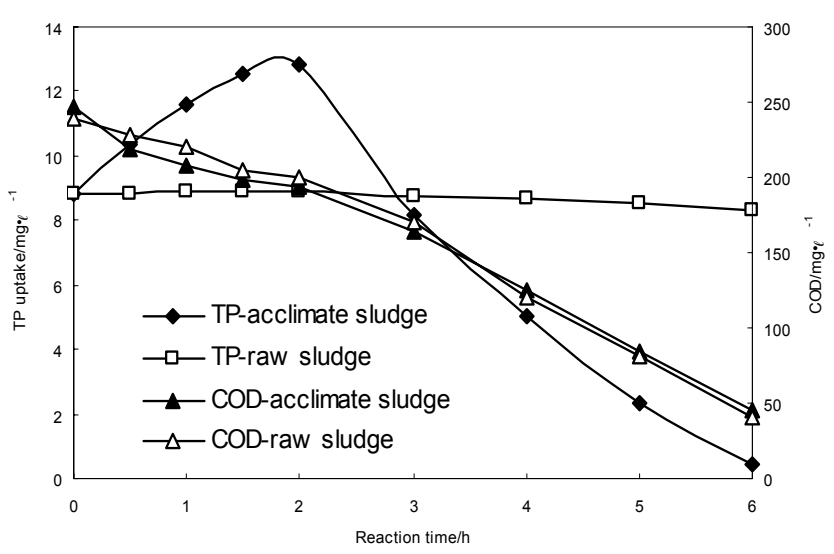

Figure 1

Variation of $C O D$ and phosphate under different sludge in $2 h$ anaerobic $-4 h$ aerobic period (one cycle)

predominant. The decrease in the number of the filamentous fungi means an improvement of sedimentation of the sludge and an increase of the treatment ability. Subsequently the microorganisms in the raw and acclimated sludge were inoculated in a isolating culture medium respectively. Four predominant bacteria were picked from the raw sludge and marked A1, A2, A3, A4; and bacteria respectively marked B1, B2, B3, B4 were picked from the acclimated sludge. The TEM photographs are shown in Fig. 2. In order to compare the microbial community structure, DGGE was used to analyse the treated samples.

\section{Analysis of DGGE pattern}

The samples were concentrated to $30 \mu \ell$ before electrophoresis. Figure 3 shows DGGE profiles of 16S rDNA fragments of samples. There existed many visible bands showing complexity and diversity of microbial ecology in the sludge samples. Since the brightness and quantity of the bands reflect the amount and species of the mixture of micro-organisms, based on the analysis results, it could be concluded that raw sludge (Lane 7) and aerobic-anaerobic acclimated sludge (Lane 6) have absolutely different patterns: The brightness of bands in Lane 7 was close to each other, which means that there are no predominant bacteria; The brighter bands of Lane 6 are thin, as the anaerobic-aerobic process is a selector of PAOs which suggested that the predominant bacteria began to dominate the sludge. The brighter bands of Lanes 6 and 7 were interlaced, coupled with the results of phosphorus-removal ability, which indicated that the long-term anaerobic-aerobic cultivation washed out some non-PAOs.

In Fig. 3, it is shown that B1 (Lane 4), B2 (Lane3), B3 (Lane 2) and B4 (Lane 1) were not corresponding with one of the brightest bands of Lane 6, their mixture electrophoresis patterns (Lane 5) was in a weaker state compared with Lane 6 . The result revealed that the pure-culture bacteria were less predominant in the acclimated sludge community and many bacteria in the sludge are difficult to culture on plate culture medium

\begin{tabular}{|c|c|c|c|c|}
\hline \multicolumn{5}{|c|}{$\begin{array}{c}\text { TABLE } 3 \\
\text { Performance and phosphate content of two sludges }\end{array}$} \\
\hline Index & $S V I /\left(m \ell \cdot g^{-1}\right)$ & $\operatorname{MLSS} /\left(g \cdot \ell^{-1}\right)$ & $\mathrm{TP} /\left(\mathrm{mg} \cdot \ell^{-1}\right)$ & 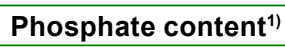 \\
\hline raw sludge & 82.56 & 5.895 & 107.75 & $1.83 \%$ \\
\hline acclimated sludge & 52.09 & 5.120 & 347.86 & $6.79 \%$ \\
\hline
\end{tabular}



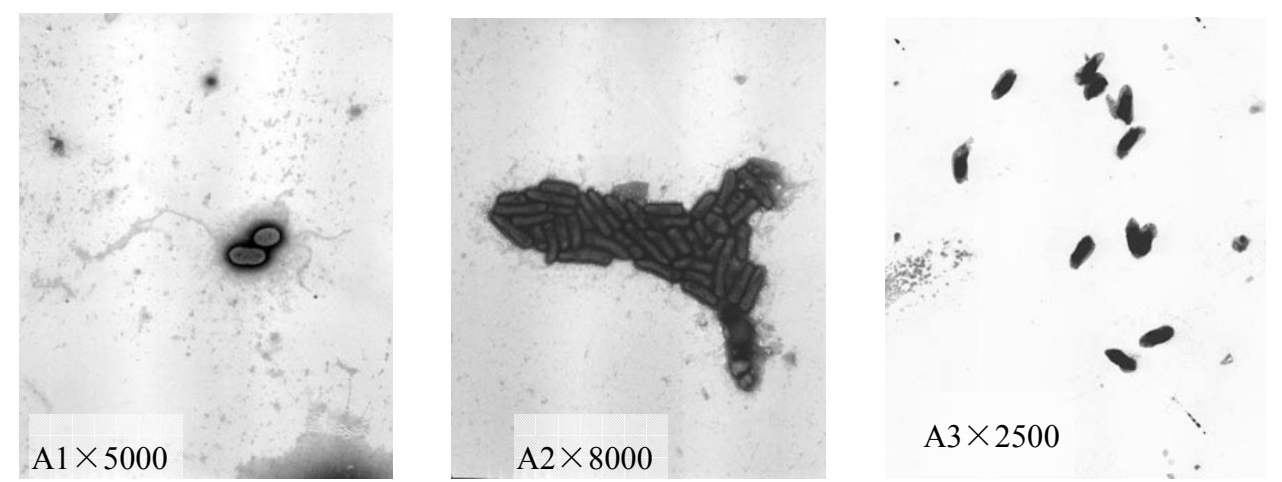

$\mathrm{A} 3 \times 2500$
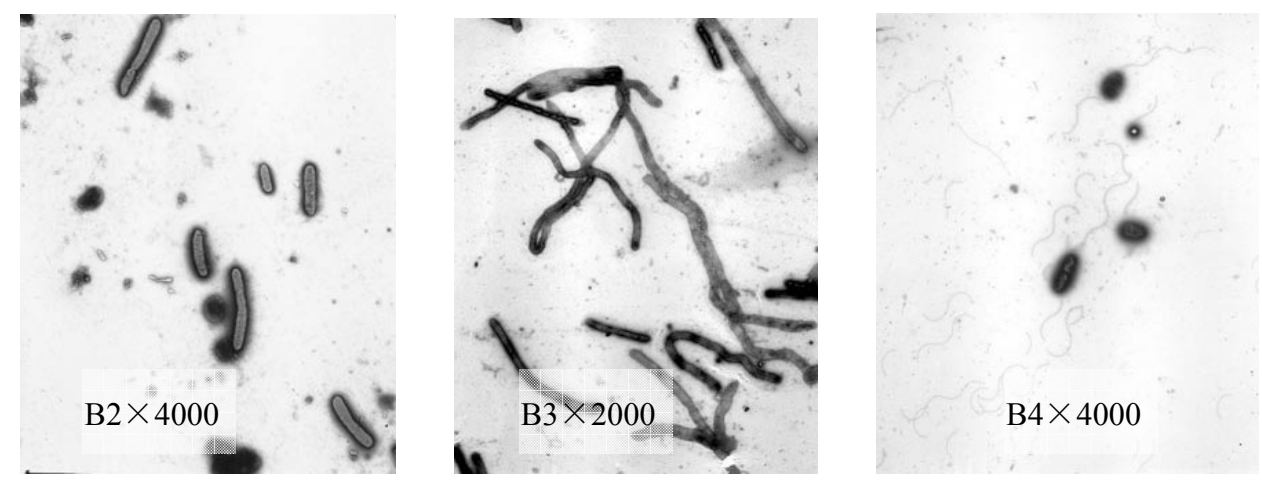

Figure 2

Photographs of dominant bacteria in raw and anaerobic-aerobic acclimated sludge by electron microscope
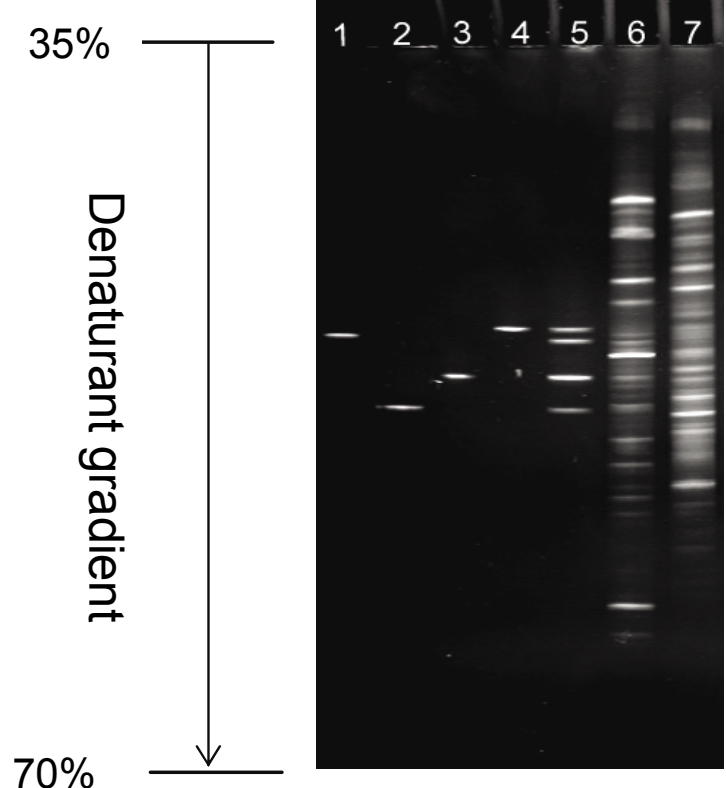

Figure 3

DGGE of $16 \mathrm{~S}$ rDNA- $V_{3}$ of raw sludge, acclimated sludge and 4 predominant bacteria

1-B4, 2-B3, 3-B2, 4-B1, 5-B1+B2+B3+B4, 6-anaerobic-aerobic acclimated sludge, 7-raw sludge

even though the main components are the same as with the SBR cultivation.

In order to identify the four pure-culture predominant bacteria, their $16 \mathrm{~S}$ rDNA fragments were PCR-amplified to $1.5 \mathrm{~kb}$ and the patterns are shown in Fig. 4.

Shanghai Bioasia (Invitrogen) Biotechnology Co. Ltd.

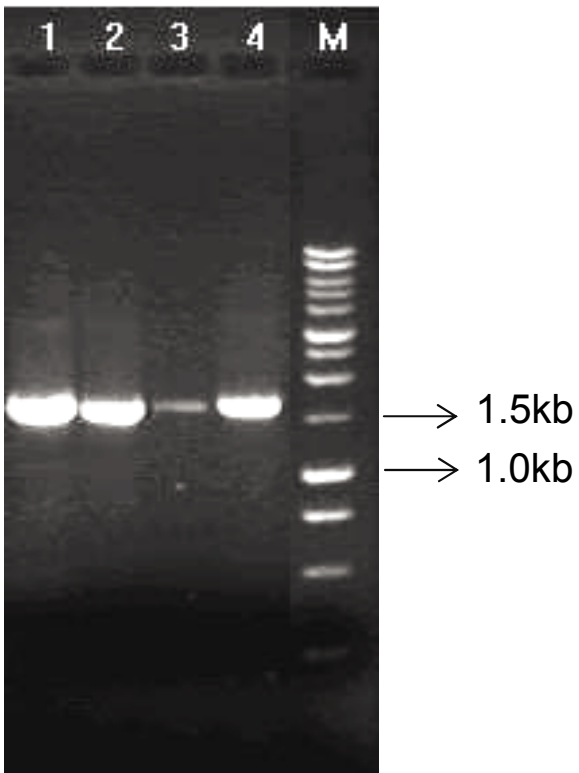

Figure 4

Electrophoresis analysis of the dominant strains by $16 \mathrm{~S}$ rDNA PCR $(1.0 \% \mathrm{gel})$

1-B1; 2-B2; 3-B3; 4-B4; 5-Marker

sequenced the PCR samples, log in on GenBank: B1 (pass over the nucleotide sequence) was $99 \%$ identified as Acidovorax sp. BSB421 (partial sequence length $=1526$ ), B2 (pass over the nucleotide sequence) was $98 \%$ identified as Sphingomonas sp. SA-3 (partial sequence length $=1444$ ).

Acidovorax sp. BSB421 and Sphingomonas sp. SA-3 were 
not so common in phosphorus removal sludge. According to the mechanisms of biological phosphorus removal, the P-uptake ties in with the formation and decomposition of poly- $\beta$-hydroxyalkanotes; some researchers reported that the PHA depolymerases separated from Acidovorax sp. (Feng et al., 2004), D (-) -3-hydroxybutyrate dehydrogenase from Acidovorax sp. Strain SA1 (Takanashi et al., 2004) and Acidovorax sp. was reported to able to remove nitriles (Wang et al., 2004) degrade aniline (Urata et al., 2004). Sphingomonas $s p$. was reported to degrade PHB (Ogita et al. 2006; Hiraishi et al. 2003), nonylphenol single isomer (Corvini et al., 2004), PAH (Wick et al., 2004), 2,4-DNT (Snellinx et al., 2003). All the above studies suggested that Acidovorax sp. and Sphingomonas sp. are not only related to phosphorus removal but also have toxic organic matter degradation ability. Zhang et al. (1998) inoculated Sphingomonas sp. to aerobic heterotrophic biofilm reactors to measure biofilm extracellular polymers and they concluded that Sphingomonas sp. could not compete well with micro-organisms derived from the mixed liquor of a wastewater treatment plant aeration basin. This may lend some support to the finding that B1 or B2 are not one of the brightest bands in Lane 6 .

For the accurate analysis of a real sludge structure, the molecular biological method may be an auxiliary to the traditional separation or identification method. Nearly $90 \%$ of micro-organisms are uncultured in the synthetic culture medium, but the molecular biological result must be confirmed with pure-culture micro-organism. The bacteria in EBPR are very complicated, the dominant micro-organisms may vary according to the different culture medium (Okunuki et al., 2004; Li et al., 2003; Lin et al., 2003; Shoji et al., 2006). The relationship of the two strains separated from PAOs with phosphorus-removal is based on their source and the formation-decomposition of PHB; more investigation is needed due to the limited molecular biological methods.

\section{Conclusion}

The sludge characteristics changed remarkably through the repeated anaerobic-aerobic process: SVI decreased from 82.56 $\mathrm{m} \ell \cdot \mathrm{g}^{-1}$ to $52.09 \mathrm{~m} \ell \cdot \mathrm{g}^{-1}$ and the phosphate content increased from $1.83 \%$ to $6.79 \%$. The acclimated sludge uptake was $12.43 \mathrm{mg} / \ell$ phosphate in a $4 \mathrm{~h}$ aerobic period; PAOs became the predominant bacteria in the SBR. The DGGE results of PCR-amplified 16S rDNA fragments showed that the electrophoresis bands were very different: there are more species of raw sludge than acclimated sludge but the predominant bacteria were not remarkable; the repeated aerobic-anaerobic process washed out some nonPAOs. Four pure-culture strains isolated from acclimated sludge have different electrophoresis patterns: they have weaker bands compared with those of the entire community, which implies that the 'real' predominant bacteria are hard to grow in any particular culture medium. The pure-culture predominant strains B1 and B2 were identified as Acidovorax sp. BSB421 and Sphingomonas sp. SA-3.

\section{Acknowledgements}

This project was supported by the National Natural Science foundation of China (50278036) and Tongji University State Key Laboratory of Pollution Control and Resource Reuse Project.

\section{References}

AHN J, DAIDOU T, TSUNEDA S and HIRATA A (2002) Characterization of denitrifying phosphate-accumulating organisms cultivated under different electron acceptor conditions using polymerase chain reaction-denaturing gradient gel electrophoresis assay. Water Res. 36 (2) 403-412.

BUCHAN L (1983) The possible biological mechanism of phosphorus removal. Water Sci. Technol. 15 87-103.

CHEN Y G, RANDALL A A and MCCUE T (2004) The efficiency of enhanced biological phosphorus removal from real wastewater affected by different ratios of acetic to propionic acid. Water Res. 38 27-36.

CORVINI PFX, MEESTERS RJW, SCHÄFFER A, SCHRÖDER HF, VINKEN R and HOLLENDER J (2004) Degradation of a nonylphenol single isomer by Sphingomonas sp. strain TTNP3 leads to a hydroxylation-induced migration product. Appl. Environ. Microb. 70 (11) 6897-6900.

FENG LD, WANG Y, INAGAWA Y, KASUYA K, SAITO T, DOI Y and INOUE Y (2004) Enzymatic degradation behaviour of co-monomer compositionally fractionated bacterial poly(3-hydroxybutyrateco-3-hydroxyvalerate)s by poly(3-hydroxyalkanoate) depolymerases isolated from Ralstonia pickettii T1 and Acidovorax sp. TP4. Polym. Degrad. Stabil. 84 (1) 95-104.

FUHS GW and CHEN M (1975) Microbiological basis of phosphate removal in the activated sludge process for treatment of wastewater. Microb. Ecol. 2 (2) 119-138.

GERSBERG RM and ALIEN DW (1985) Phosphorus uptake by Klebsiella pneumoniae and Acinetobacter calcoacetics. Water Sci. Technol. 17 (11-12) 113-118.

HIRAISHI T, KAJIYAMA M, TABATA K, YAMATO I and DOI Y (2003) Genetic analysis and characterization of poly(aspartic acid) hydrolase-1 from Sphingomonas sp. KT-1. Biomacromolecules 4 (1) 80-86.

JENKINS D and TANDOI V (1991) The applied microbiology of enhanced biological phosphate removal - Accomplishment and needs. Water Res. 25 (12) 1471-1478.

LI J, XING XH and WANG B Z (2003) Characteristics of phosphorus removal from wastewater by biofilm sequencing batch reactor. (SBR). Biochem. Eng. 16 279-285.

LIN C K, YATAYAMA Y, HOSOMI M, MURAKAMI A and OKADA M (2003) The characteristics of the bacterial community structure and population dynamics for phosphorus removal in SBR activated sludge processes. Water Res. 37 2944-2952.

LÖTTER LH (1984) The role of bacterial phosphate metabolism in enhanced phosphorus removal from the activated sludge process. Water Sci. Technol. 17 (11-12) 127-138.

MINO T, VAN LOOSDRECHT MCM and HEIJNEN JJ (1998) Microbiology and biochemistry of the enhanced biological phosphate removal process. Water Res. 32 (11) 3193-3207.

MUYZER G and RAMSING NB (1995) Molecular methods to study the organization of microbial communities. Water Sci. Technol. 32 (8) $1-9$.

MUYZER G, DE WAAL EC and UITTERLINDEN AG (1993) Profiling of complex microbial populating by denaturing gradient gel electrophoresis analysis of polymerase chain reaction-amplified genes coding for 16S rRNA. Appl. Environ. Microb. 59 (3) 695-700.

KÄMPFER P, ERHART R, BEIMFOHR C, BÖHRINGER J, WAGNER M and AMANN R (1996) Characterization of bacterial communities from activated sludge: culture dependent numerical identification versus in situ identification using group- and genus-specific rRNAtargeted oligonucleotide probes. Microb. Ecol. 32 (2) 101-121.

OKUNUKI S, KAWAHARASAKI M, TANAKA H and KANAGAWA $\mathrm{T}$ (2004) Changes in phosphorus removing performance and bacterial community structure in an enhanced biological phosphorus removal reactor. Water Res. 38 2433-2439.

OGITA N, HASHIDOKO Y, LIMIN SH and TAHARA S (2006) Linear 3-Hydroxybutyrate tetramer (HB4) produced by Sphingomonas sp. is characterized as a growth promoting factor for some rhizomicrofloral composers. Biosci. Biotechnol. Biochem. 70 (9) 2325 2329.

SCHULER AJ, ONUKI M, SATOH H and MINO T (2002) Density separation and molecular methods to characterize enhanced biological phosphorus removal system populations. Water Sci. Technol. 46 (1-2) 195-198. 
SHOJI T, NITTAMI T, ONUKI M, SATOH H and MINO T (2006) Microbial community of biological phosphorus removal process fed with municipal wastewater under different electron acceptor conditions. Water Sci. Technol. 54 (1) 81-89.

SNELLINX Z, TAGHAVI S, VANGRONSVELD J and VAN DER LELIE D (2003) Microbial consortia that degrade 2,4-DNT by interspecies metabolism: Isolation and characterization. Biodegrad. 14 (1) 19-29.

STANDARD METHODS (1992) Standard Methods for the Examination of Water and Wastewater. American Public Health Association, Washington, DC.

SURESH N, WARBURG R, TIMMERMAN M and HALVORSON H (1985) New strategies for the isolation of micro-organisms responsible for phosphate accumulation. Water Sci. Technol. 17 (11-12) 99-111.

TAKANASHI M, SHIBAHARA T, SHIRAKI M and SAITO T (2004) Biochemical and genetic characterization of a D(-)-3-Hydroxybutyrate Dehydrogenase from Acidovorax sp. Strain SA1. J. Biosci. Bioeng. 97 (1) 78-81.

URATA M, UCHIDA E, NOJIRI H, OMORI T, OBO R, MIYAURA N and OUCHIYAMA N (2004) Genes involved in aniline degradation by Delftia acidovorans strain $7 \mathrm{~N}$ and its distribution in the natural environment. Biosci. Biotechnol. Biochem. 68 (12) 2457-2465.
VAN LOOSDRECHT MCM, SMOLDERS GJ, KUBA T and HEIJNEN JJ (1997) Metabolism of micro-organisms responsible for enhanced biological phosphorus removal from wastewater. Antonie van Leewenhoek 71 (1-2) 109-116.

WAGNER M, AMANN R, LEMMER H and SCHLEIFER KH (1993) Probing activated sludge with oligonucleotides specific for proteobacteria: Inadequacy of culture dependent methods for describing microbial community structure. Appl. Environ. Microbiol. 59 (5) 1520-1525.

WANG CC, LEE CM and CHEN LJ (2004) Removal of nitriles from synthetic wastewater by acrylonitrile utilizing bacteria. J. Environ. Sci. Health - Part A Toxic/Hazardous Substances and Environ. Eng. 39 (7) 1767-1779.

WENTZEL MC, LOEWENTHAL RE, EKAMA GA and MARAIS GvR (1988) Enhanced polyphosphate organism cultures in activated sludge - Part I: Enhanced culture development. Water SA 14 (2) 81-92.

WICK LY, MATTLE PA, WATTIAU P and HARMS H (2004) Electrokinetic transport of PAH-degrading bacteria in model aquifers and soil. Environ. Sci. Technol. 38 (17) 4596-4602.

ZHANG X, BISHOP PL and KUPFERLE MJ (1998) Measurement of polysaccharides and proteins in biofilm extracellular polymers. Water Sci. Technol. 37 (4-5) 345-348.

ZHOU J, BRUNS MB and TIEDJE JM (1996) DNA recovery from soils of diverse composition. Appl. Environ. Microb. 62 (2) 316-322. 